\title{
Molecular identification and expression of papaya ringspot virus gene in tobacco (Nicotiana benthamiana Domin) plants
}

\author{
R. Mishra', R.K. Verma', N. Petrov², M. Stoyanova², A. Stoev², B. Dikova², \\ N.V. Bakardjieva ${ }^{2}$ and R.K. Gaur ${ }^{1^{*}}$
}

\begin{abstract}
Papaya ringspot virus (PRSV) belongs to Potyviridae family, genus Potyvirus and mainly transmitted by aphids (genera Macrosiphum and Myzus). Infected plants show mottling, blister-like patches and distortion of leaves as well as causes ring spot disease in papaya (Carica papaya L.) fruits. The HC-Pro (helper component proteinase), $\mathrm{Cl}$ (cylindrical inclusion), NIb (nuclear inclusion body $\mathrm{b}$ ) and $\mathrm{Cp}$ (coat protein) gene are involved in many other essential processes during the virus infection cycle as well as for transmission of potyvirus. Novel degenerate primers have been designed for amplification these genes. Phylogenetic analysis showed that the HC-Pro had the closest relationship with PRSV P isolate MP, CI with PRSV P isolate DEL and partial Nib plus CP with PRSV P isolate DEL as well as PRSV P isolate USA. Eluted PCR product of amplified gene was checked in $1 \%$ agarose gel and cloned in binary vector with reporter gene (GUS). Agroinfiltration and GUS histochemical staining was performed for detecting the movement of a particular gene. The high sensitivity of GUS assays permitted temporal analysis of early expression of potyviral genes. Expression study proved that all genes are involved in long distance movement in host plants.
\end{abstract}

Keywords: GUS activity, Papaya ringspot virus

\section{Introduction}

Papaya (Carica papaya L.), a widely grown in tropical and sub-tropical regions in the world, is commonly found in India, Australia, Hawaii, Sri Lanka and Burma. Papaya fruit is rich in vitamins $A, B_{1}$ and $B_{2}$, and contains a valuable proteolytic enzyme 'papain' that helps in digesting protein rich food. Papaya ring spot virus (PRSV) causes mottling, blister like patches and distortion of leaves as well as the ring spot disease in papaya fruits. Heavy papaya yield losses have been reported due to the infection of this virus. The PRSV is single stranded, positive sense RNA virus and is transmitted by many aphid species such as Myzus persicae. Two biotypes of PRSV (P and $\mathrm{W}$ ) have been recognized on the basis of their ability to infect papaya (Roy et al., 1999). Polymerase chain reaction (PCR) is an extremely sensitive and specific technique for the detection and identification of plant pathogens. The helper

\footnotetext{
1 Department of Science, FASC, Mody University of Science and Technology, Lakshmangarh, Rajasthan, India

2 Institute of Soil Science, Agrotechnology and Plant Protection, Sofia, Bulgaria

* Corresponding author: gaurrajarshi@hotmail.com
} 
component proteinase (HC-Pro) and coat protein (CP) genes are responsible for transmission of potyvirus through a vector. Concomitantly, the interaction between $\mathrm{HC}$-Pro and cylindrical inclusion ( $\mathrm{Cl}$ ) may be relevant to their coordinated functions in cell-to-cell movement of the virus (Mishra et al., 2013). In the present study, an attempt was made to show the expression of different PRSV genes associated with symptoms and virus movement.

\section{Materials and Methods}

Leaf samples showing the characteristic symptoms of virus infection, including mottling, blister-like patches and distortion of leaves, were collected during field investigation of Rajasthan, India in 2013.

The total RNA was extracted from the collected infected leaf using TRI Soln Genei $^{\text {TM }}$ Merk. The total RNA were reverse transcriptase by C-DNA synthesis kit (MERK, Genei, India) using Oligo (dT) as the primer by following the manufacturer's instruction. After the PCR, the amplicons were cloned in PGEM-T vector (Promega, USA) and sequenced. These genes were further submitted to National Centre for Biotechnology Information (NCBI) GenBank, USA. Phylogenetic relationship of PRSV HC-Pro, Cl, partial NIb and CP sequence was analyzed by the Neighbour-joining (NJ) algorithm implemented in MEGA v. 5.2 programs (Tamura et al., 2011).

For agroinoculation of pBl121 with Gus PRSV HC-Pro, Gus PRSV Cl and Gus PRSV partial NIb plus CP, Agrobacterium tumefaciens EHA105 was transformed with the corresponding plasmids. The agrobacterium-harboring plasmid was agroinfiltered in tobacco (Nicotiana benthamiana Domin) plants and incubated for $2-3$ days at $25^{\circ} \mathrm{C}$ under a 16/8 h light/dark cycle. The GUS histochemical staining of agroinfiltered tobacco plants were followed as described by Crone et al. (2001) to identify their expression profiles.

\section{Results and Discussion}

The amplicons for PRSV HC-Pro, Cl, Nib plus CP showed bands of 70obp, 40obp and $1500 \mathrm{bp}$, respectively, when amplified with the degenerated primers. Homology score of PRSV HC-Pro (KF956721) showed 97 \% with PRSV W7, Cl (KF738174) showed $88 \%$ with PRSV P isolate DEL and partial NIb plus CP (KF989499) showed $99 \%$ with PRSV $P$ isolate DEL. According to phylogenetic analysis, the HC-Pro had the closest relationship with PRSV $P$ isolate $M P, C I$ with $P R S V P$ isolate $D E L$ and partial Nib plus CP with PRSV P isolate DEL as well as PRSV P isolate USA (Figure 1).

In this study, the movement of various PRSV genes was investigated in terms expression through reporter gene (GUS) followed by agrobacterium transformation. The GUS staining was detected in leaf veins, stems and roots of plants harboring the three plasmids instead of wild plants (Figure 2). This study proved that these genes are also involved in cell-to-cell movement of the virus (Rojas et al., 1997). 


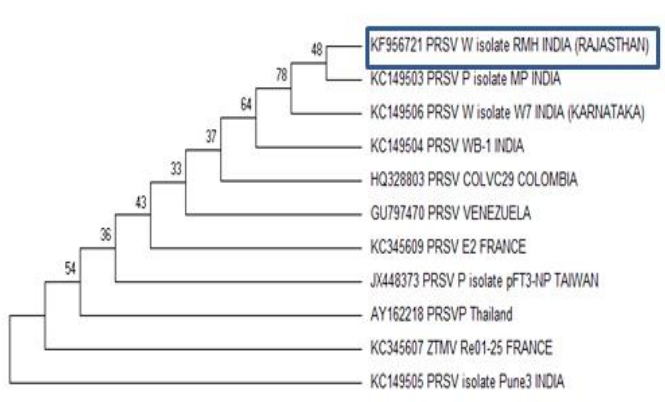

(A)

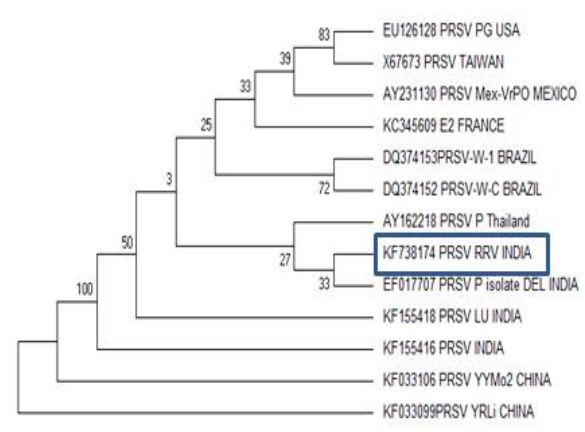

(B)

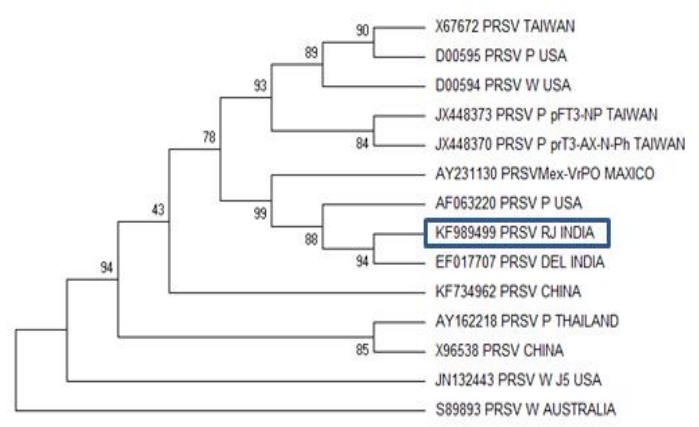

(C)

Figure 1. Phylogenetic analysis through Neighbour-joining (MEGA v 5.2) (A) HC Pro, (B) Cl and (C) partial NIb and CP

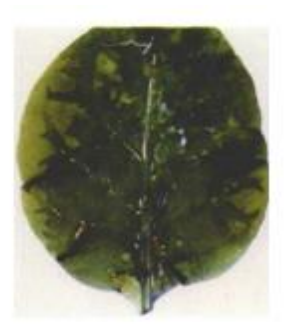

HC-Pre GUS

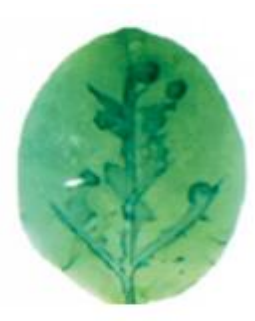

CI GUS

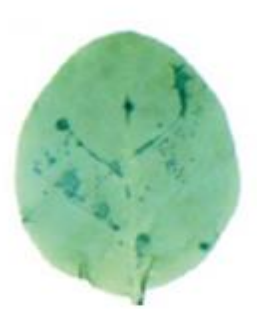

NFHCP GUS

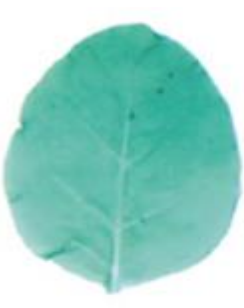

CONTROL

Figure 2. Expression of PRSV genes in Nicotiana benthamiana plant after GUS histochemical staining

\section{Acknowledgement}

The authors are thankful to Department of Biotechnology, GOI, India for the financial support (BT/PR14902/BRB/10/889/2010). 


\section{References}

Crone, D., Rueda, J., Martin, K.L., Hamilton, D.A. and Mascarenhas, J.P. (2001): The differential expression of a heat shock promoter in floral and reproductive tissues. Plant Cell Environ. 24: 869-874

Mishra, R., Verma, R.K., Sharma, P., Choudhary, D.K. and Gaur, R.K. (2013): Interaction between viral proteins with the transmission of Potyvirus. Arch. Phy. Plant Protect. DOI: 10.1080/03235408.2013.807659

Roy, G., Jain, R.K., Bhat, A.I. and Varma, A. (1999): Comparative host range and serological studies of Papaya ringspot potyvirus isolates. Indian Phytopath. 62: 14-17

Rojas, Maria R., Murilo Zerbini, F., Allison Richard, F., Gilbertson, Robert L. and Lucas, W.J. (1997): Capsid protein and helper component-proteinase function as potyvirus cell-to-cell movement proteins. Virology 237: 283-295

Tamura, K., Peterson, D., Peterson, N., Stecher, G., Nei, M. and Kumar, S. (2011): MEGA5: Molecular Evolutionary Genetics Analysis using Maximum Likelihood, Evolutionary Distance, and Maximum Parsimony Methods. Mol. Biol. and Evolu. 28: 2731-2739. 